\title{
MEMAKNAI PENERAPAN SISTEM PENGENDALIAN MANAJEMEN PADA PERUSAHAAN KELUARGA ETNIS TIONGHOA DI MINANGKABAU
}

\author{
Tabah Rizki ${ }^{1}$ dan Sany Dwita ${ }^{2}$ \\ 1) Alumni Jurusan Akuntansi Fakultas Ekonomi, Universitas Negeri Padang \\ 2) Jurusan Akuntansi Fakultas Ekonomi, Universitas Negeri Padang \\ *Korespondensi: tabah.rizki05@gmail.com
}

\begin{abstract}
This study aims to interpret in depth the cultural values of Confucianism reflected in the management control system of Chinese ethnic families in Minangkabau. This study uses qualitative interpretive. The process of this research is interactive and meaning that is not measured by statistical data and aims to explore various information more in depth and makes it possible to get things implied by data collection carried out in triangulation. Data analysis is inductive and the results of qualitative research emphasize the meaning of generalization. This interpretive research method seeks to formulate a question and then analyze it based on the question of participants' perceptions studied. This research was conducted in one of the food trading businesses in the city of Padang, namely UD. KBF. The results of the study can be concluded by interpreting Confucian cultural values in the implementation of the management system of Chinese ethnic family companies. This study found that Confucian values were reflected in the implementation of the company's management control system UD. KBF. The values applied by the company's leadership are
\end{abstract}

Keywords: chinnese etnic, kunfusianism, management control system

How to cite (APA $6^{\text {th }}$ style)

Rizki, Tabah dan Dwita, Sany. (2019). Memaknai Penerapan Sistem Pengendalian Manajemen pada Perusahaan Etnis Tionghoa di Minangkabau. Jurnal Eksplorasi Akuntansi. 1(1) Seri A, 50-63.

\section{PENDAHULUAN}

Penerapan sistem pengendalian manajemen (SPM) di perusahaan sudah menjadi salah satu fokus utama penelitian akuntansi baik di negara maju maupun di negara berkembang (Tucker et al.,2009). SPM adalah suatu sistem yang sangat penting bagi organisasi, sistem ini dapat mengarahkan atau mengatur aktivitas anggota organisasi agar sesuai dengan tujuan organisasi. Fokus kajian SPM yaitu perilaku sumber daya manusia. Keberhasilan kinerja dalam perusahaan ditentukan oleh kualitas sumber daya manusia, pimpinan, dan bawahan sehingga pemahaman dan kemampuan dalam mengoperasikan tugas masing-masing dianggap kebutuhan. Hal tersebut membutuhkan pengendalian manajemen untuk mengatasi kemungkinan seseorang melakukan hal-hal yang tidak diinginkan perusahaan.

Penelitian sistem pengendalian manajemen yang pernah dilakukan sebelumnya di Indonesia, lebih memfokuskan pada penggunaan diagnostik dan mengabaikan implikasi 
penggunaan sistem pengendalian manajemen secara terpisah untuk masing-masing sitem pengendalian sehingga belum menguji proporsi penting dari sistem itu sendiri (Henri, 2006; Ismail 2015).Saat ini, 80 persen perusahaan yang ada di Indonesia didominasi oleh perusahaan keluarga etnis Tionghoa (Hopper,2005).Perusahaan keluarga memiliki peranan penting dalam ekonomi negara maju dan berkembang yang telah banyak dibahas dalam literatur (Villalonga,2006; Astrachan \& Shanker, 2003). Namun, beberapa tahun terakhir telah memperlihatkan kemunculan orang pribumi seperti jawa dan Minangkabau sebagai pengusaha perusahaan keluarga. Penelitian akuntansi terdahulu atas bisnis keluarga Tionghoa yang berfokus pada sistem pengendalian manajemen terutama di Indonesia lebih membahas dua aspek yaitu: kepentingan perusahaan dan lingkungan budaya.

Penelitian ini berkontribusi memperdalam pemahaman tentang penerapan SPM dan lingkungan sosial budaya yang melingkupinya. Lingkungan sosial budaya memberikan ruang untuk transformasi sistem pengendalian manajemen di perusahaan keluarga serta pragmatisme bisnis kegiatan yang lebih luas. Selain itu, penelitian sistem pengendalian manajemen dengan pendekatan budaya akan menjadi kunci penting yang dapat digunakan untuk mengarahkan jalannya perusahaan, hal ini dapat menyederhanakan proses dan kontrol hasil di perusahaan keluarga.

Efferin (2010) serta Aguinis,Joo dan gottfredson (2012) menyarankan lebih banyak studi yang mempelajari bagaimana penerapan sistem pengendalian manajemen di perusahaan keluarga etnis Tionghoa diterapkan dan ditransformasikan menjadi praktik akuntansi di setiap daerah nusantara agar dapat menjelaskan isu-isu budaya terkait dengan sistem manajemen kinerja yang mendetail. Penelitian ini nantinya akan merefleksi dan sejalan dengan yang disampaikan oleh Efferin (2007) pada literaturnya yang menekankan perlunya penelitian tentang penerapan sistem pengendalian manajemen di setiap daerah Indonesia untuk memperdalam pemahaman tentang akuntansi dan realita yang melingkupinya.Penelitian ini memiliki dua fokus utama yang meneliti isu-isu terkait dengan: 1. Dinamika proses pengendalian manajemen dalam bisnis milik keluarga. 2. Pengaruh budaya masyarakat pada proses pengendalian manajemen. Oleh Karena itu, bukti empiris kecil tersedia untuk isu-isu manajerial dalam perusahaan keluarga Indonesia asli.

Penelitian ini merupakan studi kasus dari pada sistem pengendalian manajemen di perusahaan keluarga Indonesia yang dimiliki oleh etnis Tionghoa dari Minangkabau. Penelitian ini meneliti konteks budaya bisnis keluarga dan sudut pandang peserta organisasi (pemilik dan karyawan).Perusahaan keluarga etnis Tionghoa erat kaitannya dengan Falsafah dan pemikiran Konfusianisme dijadikan ideologi dasar untuk mengubah kehidupan mereka dan keluarganya dalam menjalankan bisnis usaha.Berdasarkan budaya konfusianisme menjadi dasar bagi para perusahaan keluarga etnis tionghoa dalam meningkatkan kinerja perusahaan.

Penelitian ini bertujuan untuk memaknai secara mendalam nilai-nilai budaya konfusinisme yang terefleksi pada sistem pengendalian manajemen keluarga Etnis Tionghoa di Minangkabau. Memberikan manfaat kontribusi dalam pengembangan teori dalam memaknai penerapan sistem pengendalian manajemen di Minangkabau dan menjadi bahan pertimbangan bagi manajemen dalam melaksanakan dan mengendalikan sistem pengendalian manajemen yang dimiliki oleh perusahaan dalam menjalankan aktivitas sehingga dapat berjalan dengan efektif dan efisien.

\section{REVIU LITERATUR DAN HIPOTESIS \\ Sistem Pengendalian Manajemen}

Sistem pengendalian manajemen adalah suatu kegiatan dan strategipencapaian tujuan dengan mempengaruhi dan mengendalikan semua orang dalam organisasi untuk mengimplementasikan tujuan organisasi dalam masing-masing bagiannya secara efektif dan 
efisien.Menurut Anthony dan Govindarajan (2012) mendefinisikan sistem pengendalian manajemen sebagai berikut: Sistem pengendalian manajemen (SPM) adalah suatu sistem yang sangat penting bagi organisasi, sistem ini dapat mengarahkan atau mengatur aktivitas anggota organisasi agar sesuai dengan tujuan organisasi. SPM akan menjadi alat dalam memberikan informasi dan pengimplementasian serta perumusan organisasi.

\section{Etnis Tionghoa di Minangkabau}

Indonesia adalah negara terpadat keempat di dunia dengan lebih dari 260 juta orang (2017) . Indonesia merupakan salah satu negara multietnis. Negara ini, dihuni oleh lebih dari 300 kelompok etnis yang berbicara ribuan dialek, dengan satu bahasa ibu yang disebut bahasa Melayu. Indonesia memiliki kelompok etnis yang berbeda seperti Jawa (45\%), Sunda (14\%), Madura (7,5\%), Melayu pesisir (7,5\%) dan kelompok etnis lainnya (26\%).Budaya di Indonesia adalah campuran pengaruh dari banyak peradaban beragam agama, yang meliputi: Hindu dan Budha, yang datang dari India selama awal abad pertama Masehi; pengaruh Arab selama abad ke-13, terutama melalui ajaran Islam; dan juga budaya Asia Tenggara dan Polinesia, serta pengaruh dari masuknya orang Tionghoa dan Belanda.Etnis Tionghoa adalah orang yang berketurunan Cina di Indonesia secara khas disebut sebagai yang akan mudah membedakan bahwa orang Cina sebagai Warga Negara Asing (WNA) dan orang Tionghoa sebagai Warga Negara Indonesia (WNI) (Suryadinata, 2002).

Masyarakat Indonesia secara etnis dibagi dengan Jawa dan Minangkabau sebagai kelompok etnis terbesar dan paling berpengaruh. Oleh karena itu Jawa dan Minangkabau adalah pusat dalam pengembangan Indonesia modern. Etnis Tionghoa di Minangkabau dipercaya telah memasuki Padang sebelum kedatangan penjajah. Tetapi, peran mereka semasa VOC tercatat lebih baik dibandingkan dengan masa sebelumnya. Cina tercatat sebagai partner dagang yang penting bagi pemerintah kolonial Belanda juga bagi pedagang Melayu dalam menjalankan perekonomian Sumatra Barat. Kekerabatan masyarakat Tionghoa menjadi nomor satu bagi seperti adat,orang Asia Tengah (Jepang dan Korea), mereka sangat menjaga martabat keluarga, sangat menghormati leluhur. Ini merupakan sikap dasar bagi orang Tionghoa yang dipengaruhi oleh ajaran Confunsius dan Tao yang melekat pada setiap orang Tionghoa. Etnis Cina dan Minang juga dikenal karena keberadaannya yang menjangkau semua wilayah. Populasi orang Minang sudah menyebar di hampir seluruh wilayah Indonesia, juga Tionghoa yang ada di hampir semua negara di dunia. (Erniwati,2011).

\section{Perusahaan Keluarga Etnis Tionghoa}

Penelitian perusahaan keluarga etnis Tionghoa ini dikategorikan sebagai Family Business Enterprise (FBE). FBE adalah perusahaan yang dimiliki dan dikelola oleh anggota keluarga pendirinya yang berasal dari keluarga Tionghoa di Minangkabau. Baik kepemilikan maupun pengelolaannya dipegang oleh pihak yang sama, yaitu keluarga. Perusahaan keluarga tipe ini dicirikan oleh di pegangnya posisi-posisi kunci dalam perusahaan oleh anggota keluarga (Susanto;2015). Perusahaan keluarga etnis Tionghoa adalahperusahaan di mana keluarga memiliki kepemilikan yang termarginalisasi oleh kelompokorang-orang keturunan Cina di Indonesia (Tionghoa) serta manajemen pengendali yang terdapat dalam nilai-nilai keluarga yang mereka pindahkan ke karyawan non-keluarga dan menjadi panduan kolektif untuk mencapai tujuan organisasi sehingga memiliki budaya, fisik, kelas sosial, ekonomi.

\section{METODE PENELITIAN}

Jenis penelitian ini adalah kualitatif interpretif. Menurut Sugiyono (2015), penelitian kualitatif adalah penelitian yang berlandaskan pada filsafat postpositivisme, digunakan untuk meneliti pada kondisi objek yang alamiah, dimana peneliti adalah sebagai instrumen kunci 
yang mampu memberikan gambaran yang kaya akan konteks penelitian. Proses penelitian ini secara interaktif dan makna yang tidak terukur oleh data statistik dan bertujuan untuk menggali berbagai informasi secara lebih mendalam serta memungkinkan untuk mendapatkan hal-hal yang tersirat pengumpulan data dilakukan secara triangulasi. Analisis data bersifat induktif dan hasil penelitian kualitatif lebih menekankan makna dari generalisasi. Metode penelitian interpretif ini berupaya merumuskan suatu pertanyaan kemudian dianalisis berdasarkan pada pertanyaan persepsi partisipan yang diteliti.

Penelitian ini dilaksanakan pada salah satu usaha dagang makanan di kota Padang yaitu UD. KBF. Pemilihan tempat penelitian ini sesuai dengan objeknya yaitu etnis Tionghoa dengan mempertimbangkan keadaan aktifitas operasional yang dilakukan oleh UD tersebut mengingat bahwa sebagian besar pegawai dalam UD. KBF mempunyai ajaran dan agama yang berbeda seorang pendiri UD. Keripik Balado. Pemilik perusahaan ini beragama katolik sedangkan karyawannya beragama islam. Pemilihan UD.KBF juga ditandai dengan perusahaan ini inisiasi pertama yang mendirikan kripik balado di kota padang. Selain itu ciri khas yang ditampilkan dalam setiap aktivitas perusahaan menawarkan konteks budaya konfusianisme dijalankan setiap melakukan kegiatan usaha. pemilihan sampel ini sangat unik apabila dikaji dengan melihat usaha ini dalam merancang dan mengimplementasikan SPM dengan budaya konfusianisme.

Jenis data Data primer yaitu bila pengambilan data dilakukan secara langsung oleh peneliti terhadap informan dengan wawancara mendalam (Arikunto, 2006). Wawancara mendalam dilakukan terhadap informan atau narasumber yang memahami konteks masalah yang sedang diteliti. Penelitian ini menggunakan data yang diperoleh melalui wawancara semi struktur kepada Pimpinan (Pemilik Perusahaan), Manajer Perusahaan, dan Karyawan.Data sekunder adalah data yang diperoleh secara tidak langsung yaitu melalui perantara yang didapat dari pihak ketiga seperti : literatur,tulisan,dokumentasi,tulisan-tulisan sebagai pembanding dari data yang diperoleh yaitu buku-buku referensi,koran ataupun media elektronik perusahaan keluarga etnis Tionghoa.

Dalam rangka mengumpulkan data dan informasi yang valid dan akurat, peneliti akan melakukan wawancara. Wawancara yang dilakukan oleh peneliti dibantu dengan alat perekam. Alat perekam ini digunakan untuk bahan cross check bila pada saat analisa terdapat data, keterangan atau informasi yang tidak sempat dicatat oleh peneliti. Dalam penelitian ini peneliti menggunakan empat teknik pengumpulan data yaitu wawancara semi struktur, triangulasi, observasi langsung dan analisis dokumen.

Analisis data (Sugiyono, 2013), merupakan proses mencari dan menyusun secara sistematis data yang diperoleh dari hasil wawancara, catatan lapangan, dan bahan-bahan lain, sehingga dapat mudah dipahami, dan temuannya dapat diinformasikan kepada orang lain. Pada penelitian ini tahap-tahap analisis data dilakukan untuk menentukan kategori, konsep, tema dan pola dan terakhir melakukan analisis data. Langkah-langkah dalam menganalisis data yaitu: 1. Data dikumpulkan dengan menggunakan wawancara semi terstuktur, 2. Pada saat wawancara peneliti sudah melakukan analisis terhadap jawaban wawancara, 3 . Wawancara direkan dengan alat bantuan panduan wawancara, 4. Selama pengumpulan data peneliti mengolah catatan lapangan dan hasil wawancara dengan berusaha untuk tidak mendistorsikan makna dari tanggapan narasumber selama proses pengumpulan data, 5 . Hasil transkip wawancara dikaitkan dengan theorical framework yang ada sehingga tidak bersifat bias tetapi dapat dijelaskan oleh teori tersebut, 6. Analisis wawancara melalui proses coding, 7. Klasifikasi data wawancara disesuaikan dengan tema dan kerangka konseptual yang ada dallam penelitian untuk memastikan konsistensi wawancara, 8. Dalam melakukan interpretasi selama wawancara ada kebutuhan untuk menjembatani kesenjangan antara pandangan emik (interpretasi peserta tentang pengalaman mereka) dan pandangan etik (interpretasi orang 
luar/literatur dari sebuah fenomena) (Efferin dan Hopper, 2007), 9. Kontradiksi data yang muncul akan diklarisifikasi dari hasil observasi dan analisis artikel.

\section{HASIL DAN PEMBAHASAN}

Penelitian ini berfokus pada penerapan sistem pengendalian manajemen perusahaan keluarga etnis Tionghoa pada UD.KBFdan menanyakan kepada pihak terkait dengan sistem pengendalian manajemen dalam perusahaanserta respon mereka dalam menyikapi pertanyaan terbuka yang diberikan oleh peneliti.

\section{Filosofi Bisnis Pemilik Perusahaan Keluarga UD.KBF}

Sejarah singkat Pendirian UD.KBF. Usaha ini merupakan usaha keturunan Tionghoa yang didirikan pada tahun 1970. Usaha ini dimiliki dan dikelola oleh ibuk Elisabeth beserta suaminya. awalnya usaha ini menjual keripik balado dan roti bakar dalam aktivitas usaha serta mempunyai karyawan lebih dari 45 orang. Hal ini diungkapkan oleh pimpinan usaha dan manajer pada saat wawancara :

“....awalnya dipimpin oleh mama mertua saya sejak tahun 1970,namun pada tahun 1985 digantikan dengan saya untuk melanjutkan kegiatan yang ada dengan menjual keripik balado dan roti bakar (ibu Y,Pimpinan UD.KBF)".

Pada tahun 1985, usaha ini digantikan oleh menantunya yaitu ibuk yuyu.Seiring perkembangan zaman pada tahun 1990 usaha ini mencoba meningkatkan kegiatan produksinya dengan melakukan produksi tambahan dengan menjual berbagai jenis keripik balado yang beraneka variasi. Krisis moneter yang melanda pada saat itu, usaha ini tetap bisa menjalankan strategi usahanya dengan meningkatkan produktivitas yang telah ditetapkannya. Hal ini diungkapkan oleh informan :

“....kami mencoba untuk menghemat persediaan, dengan tetap menjual produk,tapi harga cukup mahal (Ibu Y,Pimpinan UD.KBF).”

Krisis moneter yang melanda pada saat itu, usaha ini tetap bisa menjalankan strategi usahanya dengan meningkatkan produktivitas yang telah ditetapkannya. Hal ini diungkapkan oleh informan:

“....kami mencoba untuk menghemat persediaan,dengan tetap menjual produk,tapi harga cukup mahal (Ibu Y,Pimpinan UD.KBF).”

Dalam mengalami masalah diatas, Penerapan nilai hemat (qin fen) dicoba oleh pimpinan pada saat itu karena mengingat krisis keuangan yang melanda perekonomian masyarakat indonesia. Dengan mengikuti arus zaman,sumber daya sudah mulai berkurang disebabkan usaha ini tidak memproduksi roti bakar lagi. Pimpinan memberikan alternatif pada karyawan untuk tetap bergabung diusaha ini dengan bekerja memproduksi keripik balado atau kerja tempat lain dengan pimpinan bertanggungjawab kepada karyawan dengan kerjanya. Pimpinan juga menyampaikan pesan jika seandainya mereka berhenti dari tempat kerja yang ada, serta membutuhkan pekerjaan disini lagi maka pimpinan akan menolong mereka. Tanggung jawab pimpinan kepada karyawan membentuk nilai ke ji didalam pelaksanaan, pimpinan tidak mau melihat karyawan yang susah dalam kehidupannya.

Penelitian ini sejalan dengan Efferin dan Hartono (2015) bahwa filosofi kebudayaan (kepercayaan) cina melekat pada pendirinya dalam melakukan dan mendirikan kegiatan usaha bisnisnya serta tidak dapat dipisahkan dan menjadi sebuah kekuatan dalam etnis Tionghoa sehingga landasan dalam penelitian ini sebagai kekuatan utama yang dipakai dalam melakukan penghematan (qin fen) dalam sumber daya dan aktivitas ekonomi, serta hubungan sesama pekerja ( $k e j i)$.

Latar belakang sosial Anggota Organisasi UD.KBF. UD.KBF ini dipimpin oleh ibuk yuyu dan memiliki 1 orang manajer bagian manajer pemasaran dan keuangan yaitu ibuk tenten. Dalam menjalankan aktivitas,usaha ini mempunyai 20 orang karyawan tetap yang 
bekerja memiliki latar belakang sosial yang berbeda. Mereka ada yang bekerja di bagian pemasaran,pengemasan,toko, rumah tangga dan ada sopir. Mereka datang dari berbagai daerah dari pulau Sumatera, Jawa bahkan Flores dan memiliki kurun waktu yang berbeda juga dalam hal bekerja. Rata-rata karyawan UD.KBF sudah bekerja lebih dari 5 tahun. Karyawan yang bekerja di UD.KBF ini memiliki agama islam yang berbeda dari pemiliknya. Hal ini disampaikan oleh pimpinan dan manajer dalam wawancaranya :

“...13 orang berasal dari minangkabau,4 orang dari jawa,1 orang dari lampung, 1 orang flores dan 1 lagi dari bengkulu(ibu y)."

“...ada yang sudah 12 tahun bekerja, sekitar 40 tahun dan ada sekitar 32 tahun (ibu j)”.

Dengan memiliki latar belakang yang berbeda antara pimpinan dengan karyawan menyebabkan usaha dagang ini memiliki hubungan emosional dalam kekeluargaan yang mana pimpinan dan atasan sudah menganggap karyawan sebagai bagian dari keluarga mereka serta kekerabatan satu sama lain. Hal ini konsisten dengan nilai konfusianisme menghormati (Hsiao) dan percaya satu sama lain (Guanxi). Pernyataan diatas sejalan dengan penelitian yang dilakukan oleh Efferin (2007).

Budaya Organisasi UD.KBF. Peneliti menemukan ada 3 nilai yang diterapkan dalam UD.KBF ini yaitu : nilai kedisiplinan, cinta kasih dan kekeluargaan. Nilai kedisiplinan adalah iklim yang dibentuk oleh pimpinan serta manajer dan merupakan nilai tepat waktu untuk setiap melaksanakan aktivitas usaha. Nilai-nilai ini ternyata direspon positif oleh para informan. Hal ini sesuai tindakan penerapan oleh pimpinan yang berharap para karyawan dapat memahami dan mengerti keadaan yang telah ada. Berikut ungkapan dari pimpinan:

"kami menerapkan kedisiplinan (tepat waktu) bagi semua karyawan yang ada,jam 07.00 aktivitas sudah dimulai dalam perusahaan,mereka tidak lagi tunggu disuruh untuk bekerja,sudah tau dengan apa yang akan mereka lakukan di dapur usaha. Gaji yang kami berikan juga tergantung dari jam kerja mereka,dan tidak memaksakan mereka sampai target yang telah ditetapkan,namun karyawan sangat memahami dan mengerti bagaimana keadaan yang ada,sehingga mereka tidak ada yang berhenti sampai setengah hari saja,mereka sangat betah akan hal itu,berbagai upaya agar produksi yang ada,terus meningkat(Ibu Y,Pimpinan UD.kripik balado 4x7) ”.

Nilai cinta kasih (Ren dan li) merupakan : nilai landasan utama dalam ajaran konfusianisme bagi pimpinan dalam mendorong karyawannya untuk menjadi rajin dalam bekerja dan sebagai idealisme acuan serta moral tertinggi setiap pelaksanaan aktivitas sehingga mengendalikan diri sesuai dengan yang diberikan pada setiap kegiatannya. Berikut adalah petikan dari wawancara dengan pimpinan:

".....tindakan yang sesuai hati nurani adalah menjadi kunci utama dalam kelangsungan para karyawan kami,budaya cinta kasih selalu kami terapkan membuat mereka bersemangat untuk bekerja mereka dengan sendirinya akan patuh serta pamit ketika selesai kerjanya."

Nilai kekeluargaan adalah nilai yang menanamkan pemimpin untuk menjadikan karyawan merasa bagian dari keluarga yang dapat menciptakan kepedulian yang lebih untuk menjaga dan menjalankan nilai-nilai yang ada perusahaan sehingga tujuan akan tercapai.

“.....kalau misalnya tidak ada yang ngak masuk kerja,merekalah yang akan menjadi dan menggantikan posisi lainnya.(Ibu J)

“....kalau sudah selesai kami terkadang pimpinan memberikan kebutuhan (ibu U)

“......kami menghargai satu sama lain yang berada disini jika tidak sesuai dengan yang diinginkan,ibu tidak marah... tidak mau membiarkan mereka sesat" (Ibu j)

Nilai-nilai kekeluargaan (guanxi) membuat para karyawan sangat termotivasi untuk melaksanakan aktivitas usaha dan membimbing mereka ke arah yang lebih baik. Karyawan sangat menghargai $(\mathrm{Li})$ dan senang jika dianggap keluarga oleh rekan-rekannya terutama oleh 
pemimpin. Adanya nilai-nilai kekeluargaan membuat mereka merasa nyaman dalam bekerja yang berdampak pada meningkatnya motivasi karyawan.

Hasil penelitian ini relevan dengan beberapa penelitian sebelumnya yang menyatakan adanya hubungan antara budaya organisasi atau nilai-nilai organisasi dengan pengendalian manajemen (Anthony dan Govindarajan 2007; Efferin dan hopper 2007,Hofstede 1980). Penelitian ini mengungkap bagaimana nilai-nilai organisasi yang berhubungan dengan pengendalian manajemen mampu memengaruhi pengendalian manajemen. Lebih dari itu penelitian ini berhasil mengidentifikasi nilai-nilai apa saja yang mampu untuk memotivasi karyawan sehingga mereka berperilaku sesuai dengan tujuan dan harapan dari UD.Kripik balado $4 \times 7$.

\section{Nilai-nilai Kultural yang Dianut dan Hubungannya dengan Filosofi Hasil Pengendalian}

Cara Mengatur Anggaran UD.KBF. Proses dan cara penetapan anggaran pada UD .KBF dilakukan dengan menggunakan metode top-down. Metode top-down diterapkan untuk anggaran penjualan, produksi dan bahan baku usaha. Metode top-down dalam usaha ini pimpinan sebagai atasan yang akan mengatur anggaran dengan meminta hasil kegiatan dari manajer. Anggaran disusun olehibuk pimpinan (Ibu Y) serta dari manajer pemasaran dan keuangan (Ibu J). Ibu Y menerapkan nilai sosial horizontal budaya Jinshen (kehati-hatian) dan berhemat (Qin Jian) dalam melakukan penyusunan anggaran penjualan,produksi dan bahan baku. Ibu Y akan menentukan target penjualan berdasarkan jumlah barang dan produk yang diminta oleh pelanggan dengan mempertimbangkan langsung kemampuan kebutuhan produksi yang ada di toko. Ibu Y tidak langsung menyetujui jumlah pesanan yang diminta tanpamelakukan perhitungan dan melihat kapasitas produksi yang mampu diproduksi dengan hasil jual yang disetor oleh manajer perminggunya.Hal ini diungkapkan dalam wawancara ibu I:

“.....Ibu yuyu juga mempertimbangkan bahan baku serta sudah berapa banyak barang yang telah terpakai."

Hasil penelitian ini sesuai dan sejalan dengan temuan Efferin \& hopper (2007)bahwa penyusunan anggaran dengan memperhatikan situasi lingkungan khususnya ekonomi serta penerapan nilai budaya tionghoa dapat mempermudah adaptasi dan tindakan antisipasi perusahaan terhadap perubahan menunjukkan adanya praktik Jinshen (kehati-hatian dan pemikiran kedepan) sehingga dapat meningkatkan performa perusahaan.

Target Penjualan UD.KBF. Berdasarkan observasi pada dokumen serta wawancara UD.KBF, Berbagai hal juga sudah dipromosikan untuk target penjualan ini setiap bulannya, ada yang melalui online serta mengikuti event setiap kegiatan yang ada. berikut adalah hasil wawancara dan gambar:

“....kami melakukan penjualan ini bisa dipesan melalui via media sosial dan bisa langsung ke toko kami. (Ibu Y,pimpinan UD.KBF)"

Ada beberapa faktor yang menjadi landasan bagi Ibu Y selaku pimpinan UD. KBF untuk menargetkan penjualan ini. Pertama,ibuk pimpinan menerapkan nilai budaya konfusianisme $\mathrm{Li}$ (tidak memaksakan) dan merasa kasihan dengan keadaan sumber daya dalam melakukan produksi. Kedua, melihat kondisi ekonomi,misalnya terjadi kenaikan,maka barang yang akan dijual juga naik begitu juga sebaliknya. Ketiga, penerapan nilai guanxi dalam menjalin hubungan relasi yang kuat serta sosialiasi keluar dalam mempromosikan UD.KBF ini,sehingga pendapatan yang didapatkan setiap periode di usaha ini selalu meningkat.

Hal ini sejalan dengan penelitian yang dilakukan oleh Henri (2006) dan ismail (2013) menyatakan bahwa SPM yang efektif dapat dilakukan dengan meningkatkan strategi dan kemampuan kapabilitas yang mampu meningkatkan kegiatan operasional perusahaan. 
Penelitian diatas menunjukkan bahwa strategi penjualan dilakukan UD.KBF melalui via media sosial dan menjalin hubungan relasi dengan pihak luar guna meningkatkan produktivitas usaha. Selain itu,temuan dari weinsten (2007) relevan dalam hal menghadapi saingan usaha harus ada strategi yang kompetitif untuk bertahan dalam meningkatkan kegiatan usaha.

Barang yang cacat atau rusak UD.KBF. Pimpinan akan meneliti dan berhati-hati dalam hal volume produksi, anggaran pembelian bahan langsung, barang produksi yang masuk ketoko, dan tingkat cacat produksi serta barang yang akan habis masanya. Pimpinan UD.KBF mempercayai setiap barang produksi yang ada dalam toko ke karyawan. Berikut adalah petikan hasil wawancara pimpinan :

“....kami selalu mengecek dan berhati-hati setiap pemasokan barang kedalam toko,....saya percaya langsung ke mereka berapapun produksi barang yang masuk (ibu $Y$ ).

Barang yang rusak atau habis kemasannya yang berada di dalam UD.KBF ataupun dibawa ke pelanggan tidak mendapatkan potongan harga karena barang tersebut akan dikonsumsi oleh masyarakat luas,agar pelanggan semakin banyak yang datang,barang tersebut ditarik dan diambil kembali. Hal yang ada diatas, ini juga dilakukan ke pihak pelanggan yang menjadi agen penjualan UD.KBF. Barang yang telah diantar ke agen, jika didapatkan dan ditemukan barang rusak atau cacat produknya,maka tugas dan tanggungjawab dari yang mengantarnya tadi,harus segera dikembalikan dan diambil yang baru.Penelitian tersebut konsisten dengan (Birbnbaum \& wong,1985;Harrison et al.1994) yang menyatakan bahwa pemilik akan mengeksekusi kegiatan kunci di organisasi. Aturan dan tanggung jawab ini juga dilihat dari kepercayaan yang total, rasa hormat, kejujuran, kekuasaan serta rasa partisipasi yang memiliki.

\section{Tindakan Pengendalian}

Sistem akuntansi UD.KBF. UD.KBF menggunakan sistem akuntansi berbasis pada teknologi yaitu scanner yang dipegang dan dikelola oleh pihak kasir dan manajer keuangan dari anggota keluarga ibuk pimpinan. Hal ini dijelaskan oleh informan :

"....usaha dagang sudah memakai sistem scanner untuk mengecek barang...beliau sudah mempercayakan dan wewenangnya kepada adeknya untuk kegiatan itu .”(ibu I,Karyawan Rumah Tangga).

Penggunaan komputer pimpinan memberikan kepercayaan (guanxi) serta wewenang kepada ibuk manajer dari anggota keluarganya untuk mengelola secara langsung komputer berbasis scanner dalam kegiatan UD.KBF. Penerapan pada sistem akuntansi pada UD.KBF ini relevan dengan penelitian (Suryadinata,1978) dengan identitas diri dan tatanan sosial dalam hubungan yang horizontal pada pihak keluarga dalam rangka menumbuhkan kerahasiaan dan kepercayaan gunanya untuk melindungi sumber daya didalam hubungan lingkaran garis keturunan keluarga.

Penetapan Harga Jual UD.KBF. Penetapan harga jual sendiri akan ditentukan oleh pimpinan dengan manajer pemasaran dan keuangan. Dalam menetapkan harga jual pada UD.KBF,ada 3 hal yang dipertimbangkan oleh usaha ini untuk menetukan harga yang akan diberlakukan ke pelanggan,diantaranya yaitu : penetapan harga standar, survey harga pasar, dan keadaan bahan baku pada saat itu. Usaha ini melihat dari kegiatan yang telah ada,bahwa harga yang dibuat kepada pelanggan biasanya tidak jauh berbeda dari toko yang menjual barang dagangan yang sama dengan usaha ini. Hal ini diungkapkan oleh informan :

“.....karena kami udah lama berjualam jadi kami biasanya sudah bisa menetapkan harga standar (Ibu J, Manajer pemasaran dan keuangan)."

Temuan dari penetapan harga jual ini sejalan dengan penelitian yang dilakukan Batonda dan perry (2003) yang menyatakan perusahaan selalu melakukan kompromi pada 
pihak keluarga dalam penyusunan harga jual dan anggaran dan cenderung menghindari konflik (Tuoxie).

Pertanggungjawaban pengendalian. Karyawan diharapkan untuk mematuhi pemilik berupa perintah yang dijalankan,setia berbakti (Hsiao),rajin (Qin Fen), membantu satu sama lain dan menjadi jujur dan tulus (Chung) dalam melaksanakan tugas dan wewenang. Harapan ini tentunya mempunyai legitimasi budaya dengan pemilik dan karyawan UD.kripik balado 4x7. Hal ini diungkapkan oleh informan :

“.....misalnya ada permasalahan didapur langsung dibicarakan dan ditangani oleh saya sendiri (Ibu Y,Pimpinan UD.KBF)

Penerapan nilai budaya konfusianisme pada UD.KBF pada saat pimpinan memberi tugas pada karyawan dan memperingatkan mereka berupa perintah yang dijalankan,setia berbakti (Hsiao),rajin (Qin Fen) ketika pekerjaan telah selesai dilaksanakan dilaporkan keatasan agar pimpinan memahami apa yang terjadi dan salah dalam aktivitas usaha agar nantinya bisa dievaluasi.

\section{Budaya Pengendalian}

Open recruitment UD.KBF. Usaha ini memilih karyawan baru yang sesuai dengan kriteria ditentukan dan dianggap layak melalui penyampaian secara lisan kepada karyawan yang memiliki kinerja bagus untuk mencari teman atau kerabatnya dapat bekerja di usaha dagang ini untuk dilihat dalam proses recruitment. Hal ini diungkapkan oleh informan :

"....saya meminta para karyawan disini untuk mencari teman atau kerabatnya yang bisa loyal didalam bekerja." (Ibu Y,Pimpinan UD.KBF)”.

“.....kami tidak ada syarat-syarat khusus seperti pada perusahaan umumnya kayak melampirkan biodata, CV,ataupun segala macamnya (Ibu Y,Manajer Pemasaran)

“....info kerja sendiri memang tidak ada disebarluaskan ke online ataupun di iklankan begitu,Cuma disini akan diketahui dari pihak kerabat dengan kita yang secara langsung mengatakan bahwa di usaha ini ada buka lowongan kerja (Ibu I,Karyawan Rumah Tangga).”

Penerapan nilai budaya konfusianisme dalam proses recruitment dapat dilihat dalam hal kepercayaan (Guanxi) pimpinan kepada karyawan untuk mencari pekerja baru. Kemudian dalam menentukan karyawan yang akan bekerja di UD.KBF lebih selektif dan berhati-hati (Jing Shen) dengan melihat aspek etika,moral dan loyalitas. Jika pimpinan tidak sesuai dengan karyawan baru yang ada,maka akan ditegur dan dievaluasi (Hsiao) pelaksanaan kerjanya.

Menciptakan rasa aman dan nyaman dalam UD.KBF. Rasa kekeluargaan yang digunakan dalam UD.KBF antara pimpinan dengan bawahan akan menimbulkan rasa aman dan nyaman tercipta dengan sendirinya kedekatan,kebahagiaan dan rasa memiliki satu sama lain. Hal ini di ungkapkan oleh informan :

"untuk menciptakan keharmonisan serta kenyamanan dalam perusahaan ini,saya sudah menganggap mereka keluarga sendiri. Salah satu hal yang perlu di ingat yaitu jangan bentak mereka ya... kita tulus dan iklas saja jika mereka ada kesalahan,kita evaluasi dan arahkan agar mereka tidak salah dalam menjalankan kegiatannya. Jangan cerewet setiap ada hal yang tidak sesuai dengan yang kita berikan,kita berikan keluwesan dan tidak memisahkan dengan apa yang dilakukan (Ibu Y,Pimpinan UD.KBF)

“....sikap ramah dan penyanyang kepada kami semua membuat ibuk masih tetap disni,terkadang keluh kesah ibuk pasti diceritakan disini,ibuk menganggap disini adalah keluarga kedua ibuk (ibu I,Karyawan Rumah Tangga).

Penerapan nilai budaya konfusianisme dalam menciptakan rasa aman dan nyaman didalam perusahaan,tercermin dalam rasa kekeluargaan (Guanxi) pimpinan menganggap 
karyawan bagian dari keluarga mereka. Pimpinan tidak memarahi setiap pekerjaan yang ada namun akan dilakukan evaluasi ( $\mathrm{Li}$ ). Sikap ramah dan tamah (hsiao) kepada karyawan menyebabkan mereka betah di UD.KBF. Memberikan kebebasan (Ke ji) dan fasilitas sehingga mereka loyal dengan kerjanya.

Menghormati perbedaan agama sesama karyawan. Dalam pelaksanaan kegiatan UD.KBF,rasa menghormati dan menghargai serta toleransi sangat terasa antara pimpinan dan karyawan. Pimpinan selalu menghimbau,mengajak dan mengontrol mereka ketika pelaksaan beribadah masuk waktunya. Hal ini diungkapkan oleh informan :

“.....ibuk sangat toleran terhadap kita berbeda agama dengan beliau. Baliau selalu mengingatkan kami untuk beribadah,apalagi jumatan pasti ibuk tu selalu memberitahu bagi yang laki-laki untuk segera sholat. Pas waktu sholat pun semua pekerjaan di henti. Kami disuruh istirahat dan segera untuk sholat (Ibu U,Karyawan Produksi).

Hal ini sejalan dengan penelitian dilakukan oleh Efferin dan Hartono (2010) bahwa karyawan memilih untuk bertahan di perusahaan,karena mereka merasa pemimpin peduli terhadap keberadaan dan kemajuan mereka,bahkan perusahaan menjadi tempat belajar untuk perkembangan diri.

\section{Penerapan Nilai,Etnis, dan Sosial Kultural dalam merancang sistem perencanaan dan pengendalian yang ada di UD.KBF}

Insentif atau gaji pada UD.KBF. Pada UD.KBF pemberian insentif diberikan kepada karyawan dengan bentuk komisi. Penetapan target komisi yang diberikan tiap karyawan akan berbeda tergantung dari jam kerjanya dan kinerja yang diberikan. Berikut adalah hasil kutipan wawancara :

“....kami memberikan gaji/insentif kepada karyawan tergantung dari lama mereka bekerja,maksudnya tergantung dari sif jamnya mereka bekerja,jadi setiap karyawan mendapatkan perhitungan gaji yang berbeda(Ibu Y,pimpinan UD.KBF)

“...jika kita sering masuk,dan mengikuti full jam kerjanya kita insyallah dapat banyak (Ibu U,Karyawan Rumah Tangga).

Penelitian ini sejalan dengan yang dilakukan oleh Ruth Rungkat (2014) bahwa pemberian gaji atau komisi lebih kepada karyawan merupakan rasa terima kasih yang diberikan oleh pimpinan. Pimpinan menganggap bahwa setiap karyawan sudah bekerja keras untuk mendapatkan hasil yang maksimal dalam bekerja.

Ketercapaian kinerja (Pemberian Reward) UD. KBF. Pimpinan akan memberitahu kepada karyawan dan dipanggil oleh beliau dan menanyakan keinginan kita. Adanya penghargaan yang diberikan tersebut dapat memicu atau memotivasi karyawan untuk bekerja lebih keras dengan hasil yang memuaskan untuk dapat memperoleh penghargaan tersebut. Hal itu secara tidak langsung ikut memengaruhi pengendalian personel karena karyawan dapat termotivasi kerja. Hal ini diungkapkan oleh informan:

"pencapaian hal yang telah mereka lakukan disini,sangat kami beri apresiasi terhadap mereka. Kami menghargai dan beri hadiah serta fasilitas-fasilitas yang mendukung untuk keberlangsungan mereka sendiri. jadi ibuk yuyu tidak segan-segan nanya langsung kemereka apa yang mereka mau dikasih dari ibuk sendiri. tanpa ragu ibuk tu langsung hari itu juga meskipun udah dipersiapkan jauh-jauh hari. Memberikan sesuatu apresiasi ini sebagai bentuk untuk teman-teman karyawan lainnya semangat lagi untuk bekerja (Ibu J,Manajer Pemasaran dan Keuangan).

Penelitian diatas juga sejalan denganEfferin \&Hopper (2007) menyatakan bahwa sistem penghargaan dan kompensasi berfokus pada memotivasi dan meningkatkan kinerja individu dan kelompok dalam organisasi dengan mencapai kesesuaian antara tujuan dan kegiatan mereka dengan organisasi. Argumen dasarnya ialah penghargaan dan kompensasi 
menyebabkan peningkatan upaya dibandingkan dengan tidak adanya imbalan dan kompensasi yang dinyatakan secara eksplisit.

Hubungan dengan masyarakat sekitar UD.KBF. Toleransi, menghargai dan Komunikasi sangat diperlukan dalam mendukung kelancaran dan performa perusahaan sehingga dapat menjaga hubungan yang harmonisasi satu sama lain. Tanggap terhadap lingkungan menjadi salah satu bentuk kepedulian UD.KBF dalam menjalankan usahanya. Hal ini diungkapkan oleh informan :

“....ada rumah warga yang kotor karena dampak dari usaha ini,maka ibuk akan menyuruh kami untuk membersihkan pekarangan mereka. Kalau tidak yaa kami akan inisiatif sendiri membersihkannya (Ibu I,Karyawan bagian pengepakan kemasan)

"....Kami akur dan akrab selalu menjalin komunikasi,terkadang kami menanyakan kepada mereka apa yang dibutuhkan oleh mereka kami akan penuhi. Jika mereka sakit maka kami akan membawa mereka bahkan ada yang kami beli langsung obatnya(Ibu J,Manajer pemasaran dan keuangan).

Penerapan nilai budaya konfusianisme dalam menjalin hubungan dengan masyarakat sekitar dalam menjalankan UD.KBF yaitu berupa : rasa nilai menghormati dan menghargai dalam menjalankan kegiatan usaha. Peduli terhadap sesama dan lingkungan sesuai dengan kebutuhan yang diperlukan. Bijaksana dalam memimpin usaha sehingga mendapatkan pandangan yang positif terhadap masyarakat.

Respon Kerja UD.KBF. Aktivitas dalam UD.KBF dapat berjalan dengan baik, apabila karyawan satu sama lain bisa memahami dan mengerti apa yang seharusnya dikerjakan dalam aktivitas perusahaan. Hal ini sesuai dengan yang disampaikan oleh informan:

“.......saling mengisi satu sama lain. Kami tidak pernah kejanggalan dan kesalahan yang telah dilakukan didalam usaha ini. Alhamdulillah berjalan dengan lancar sesuai dengan yang diinginkan (Ibu $\mathrm{H}$,karyawan bagian administrasi Toko).

Hal ini sejalan dengan penelitian oleh Efferin \&Hartono (2012) serta Chua et al (2003) peningkatan sumber daya dapat memastikan dasar untuk kemakmuran jangka panjang bisnis keluarga dan mentransformasikan kesadaran karyawan terkait nilai-nilai dan perilaku kepentingan organisasi. Penelitian ini menunjukkan dengan adanya kemauan dan kemampuan membuat karyawan lebih loyalitas pada tempat usaha bisnis.

Pembagian sumber daya bekerja. Sumber daya yang bekerja di UD.KBF dibagi menjadi tiga bagian. Bagian satu yaitu bagian toko. Berdasarkan hasil observasi, bagian toko merupakan karyawan yang memiliki usia masih muda dan yang baru serta mampu melayani pelanggan dalam menjalankan usahanya dan digunakan dalam kegiatan pemasaran. Hal ini diungkapkan oleh informan :

“....Biasanya bagi yang masih muda ibuk tempatkan ditoko (Ibu I,karyawan Rumah Tangga).

Bagian kedua merupakan bagian dapur. Bagian dapur ini meliputi karyawan dalam pembuatan produk (produksi) serta kemasan. Berdasarkan observasi, Pada bagian ini karyawan yang sudah lama bekerja dan memiliki kemampuan dalam mengolah bahan baku serta membuat keripik balado. Hal ini diungkapkan informan :

“.... Biasanya yang sudah lama disini,diletakkan dibagian dapur atau produksi,soalnya mereka lah yang sudah tau terkait dengan produk yang akan dijual (Ibu U,Karyawan Rumah Tangga).

Bagian ketiga merupakan bagian rumah tangga. Bagian rumah tangga ini karyawan perempuan yang membantu dan membersihkan rumah serta masak untuk kebutuhan anggota keluarga dan karyawan. Hal ini diungkapkan oleh informan :

“....ada yang sudah tua ibuk-ibuknya ibuk letakkan di rumah untuk membantu membereskan kegiatan yang ada (Ibu J,Karyawan Bagian Pengemasan). 
Penjelasan dapat diketahui bahwa dalam pembagian sumber daya bekerja, pimpinan menerapkan nilai budaya konfusianisme dalam melaksanakan aktivitasnya seperti : rasa kekeluargaan (Guanxi) dalam bekerja untuk saling mengisi satu sama lain. Pada saat melaksanakan kerja pimpinan akan menanyakan kesanggupan dan kemampuan (ke ji) karyawan untuk bekerja. Pembagian kerja di UD.KBF secara adil (Qin Jian) sesuai dengan porsi yang ada. Pimpinan selalu memberitahu dan memperingatkan (Hsiao) setiap kerja yang ada.

\section{Faktor Pengaruh Lain yang Mempengaruhi Kesuksesan UD.KBF.}

Penerapan nilai cinta kasih. Cinta kasih adalah salah satu nilai konfusianisme yang diterapkan oleh pimpinan dalam upaya mencapai target usaha yang dilakukan setiap kegiatan usaha. Cinta kasih ini menggambarkan bagaimana pimpinan mendorong semangat karyawan di UD.KBF dalam melakukan aktivitas serta tidak melakukan hal yang diluar kendali usaha. Hal ini diungkapkan oleh pimpinan :

“.....karena kami menerapkan cinta kasih untuk mereka maka hal itulah yang mendorong usaha ibuk bisa berkembang sampai saat ini,tanpa mereka perusahaan ini bukanlah apa-apa.

“....keharmonisan dan cinta kasih tadi itulah yang menjadi dasar kami dalam menerapkan aktivitas yang aman terkendali dalam pelaksanaannya."

Nilai cinta kasih memberikan karyawan lebih leluasa untuk melakukan pekerjaan didalam aktivitasnya serta pimpinan selalu mengontrol kegiatan yang dilakukan dan memberi evaluasi setiap akhir kegiatan.

Keadaan sosial,ekonomi dan politik. Sosial bisa dilihat dari masyarakat dan pelanggan yang berkunjung sehingga pendapatan yang dimiliki UD.KBF setiap bulannya naik. Selain itu,hubungan dengan masyarakat sekitar usaha ditandai dengan sikap ramah,akur dan rukun serta adanya masyarakat yang mendukung positif adanya UD.KBF. Politik di tandai dengan adanya hari-hari tertentu dalam keadaan yang tidak bisa ditentukan. Hal ini diungkapkan oleh informan :

“..... Kita bisa melihat jika pelanggan banyak yang datang kesini,omset bisa banyak masuk pada saat itu,apalagi kami menjalin relasi kepada dinas ataupunpihak luar membuat usaha kami sekian hari bertambah peningkatan (Ibu J,Manajer pemasaran dan keuangan)

"....keterlibatan dari pihak lain dalam memberikan kritikan dan saran untuk keberlanjutan usaha kami,kami terus perbaharui untuk selangkah lebih maju.

Mengelola keuangan. Setiap keuangan yang dikeluarkan pimpinan tidak merasa pelit kepada karyawan dalam pembagiannya. Hal ini diungkapkan oleh informan :

“....Manajemen keuangan sangat hati-hati kami dalam mengatur porsi yang telah ada,walau dalam kondisi bagaimanapun (Ibu J,Manajer Keuangan dan pemasaran)

"....Ibuk ini juga tidak pelit akan hal keuangan,walaupun mempunyai target dan tujuan yang ingin dicapai(Ibu U,Karyawan bidang produksi).

Loyalitas dan Etos kerja karyawan. Berdasarkan hasil pengamatan pada dokumen (koran) bahwa perusahaan dengan keturunan Tionghoa memiliki etos kerja yang tinggi di akibatkan oleh pimpinan yang selalu menghargai hasil jerih payah karyawan dalam bekerja,tidak menganggap bawahan itu adalah pembantu dalam pekerjaan,ulet,rajin dan berhati-hati dalam keadaan apapun di usaha serta kebijakan yang tepat. 


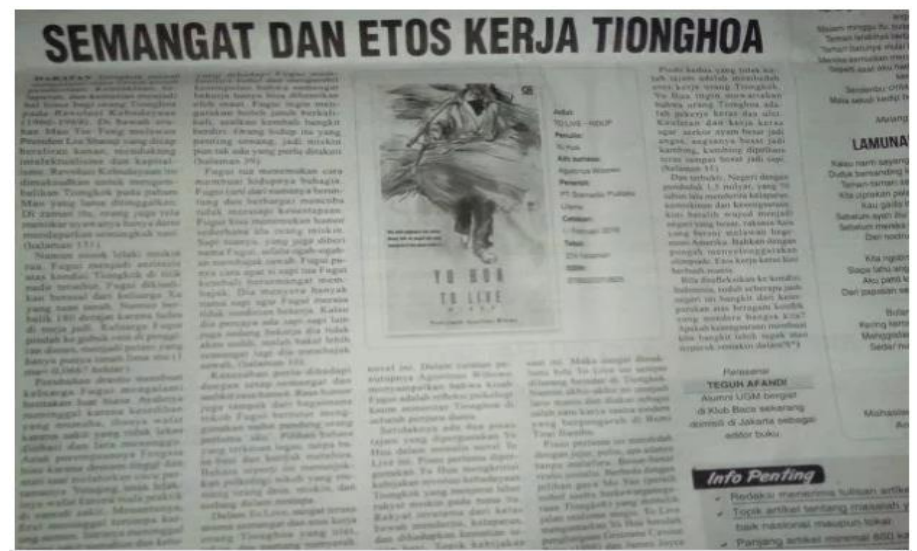

Rasa kekeluargaan. Rasa kekeluargaan yang ada di UD.KBF sangat terasa di antara anggota usaha. keakraban antara karyawan dengan pimpinan tercipta dengan adanya kebersamaan diantara anggota badan usaha. rasa kekeluargaan yang sudah melekat akan membuat karyawan betah didalam usaha. pimpinan UD.KBF menganggap mereka adalah bagian dari keluarga sendiri sehingga setiap pekerjaan yang mereka lakukan diusahakan sesuai dengan batas kemampuan dan tidak dipaksakan. Hal ini sesuai yang diungkapkan oleh informan :

“...Didalam pelaksanaan nya kami tidak ada menggangap bawahan itu rendah atau sebagai pembantu didalam perusahaan tapi menganggap mereka keluarga sendiri,tersetah mereka mau melakukan apa saja (Ibu J,Manajer Pemasaran dan Keuangan).

\section{SIMPULAN, KETERBATASAN DAN SARAN Simpulan}

Berdasarkan hasil pembahasan dapat diperoleh kesimpulan sesuai dengan rumusan masalah penelitian ini, yaitu memaknai nilai-nilai budaya konfusianisme pada penerapan sistem pengendalian manajemen perusahaan keluarga etnis Tionghoa. Penelitian ini mendukung temuan dari Efferin \& Hopper (2007) bahwa perusahaan etnis Tionghoa pada UD.KBF menerapkan nilai-nilai budaya konfusianisme dalam menjalankan bisnis usaha. Temuan juga menunjukkan bahwa penerapan sistem pengendalian manajemen pada perusahaan keluarga etnis Tionghoa UD.KBF sudah baik dilaksanakan.

Penelitian ini menemukan bahwa nilai-nilai konfusianisme terefleksi pada penerapan sistem pengendalian manajemen perusahaan UD.KBF. Nilai-nilai yang diterapkan oleh pimpinan perusahaan yaitu : guanxi (Kepercayaan), Jing shen (Berhati-hati), ke ji (Hubungan yang baik), Qin Jian (Adil), Qin Fen (Hemat), Hsiao (Menghormati), Ren dan li (Cinta Kasih), Li (Menghargai), Tuoxie (Menghindari konflik) dalam menjalankan dan fungsi sistem pengendalian manajemen.

\section{Keterbatasan}

Keterbatasan dalam penelitian ini adalah dalam hal informan. Informanyang dipilih adalah beberapa karyawan,pimpinan dan manajer yang disekiranya bisa melakukan wawancara dalam suatu perusahaan, namun dalam kenyataannya sulit untuk diwawancarai karena aktivitas yang dijalankan usaha cukup padat. Kemudian penelitian ini hanya sebatas perusahaan keluarga etnis Tionghoa saja yaitu UD.KBF serta penelitian ini dilakukan dalam waktu yang relatif pendek.

\section{Saran}

Penelitian ini bertujuan untuk memaknai penerapan sistem pengendalian manajemen pada perusahaan keluarga etnis Tionghoa. Permasalahan yang ditemukan dari hasil penelitian 
diharapkan dapat berguna sebagai bahan evaluasi bagi perusahaan keluarga terkhususnya keturunan Tionghoa agar sistem pengendalian manajemen ini dapat dilaksanakan sebaik mungkin. Saran yang penulis berikan berdasarkan hasil penelitian ini yaitu :

1. Penelitian selanjutnya

Berdasarkan keterbatasan penelitian,maka saran untuk penelitian selanjutnya adalah sebaiknya pemilihan perusahaan keluarga etnis Tionghoa lebih menyebar. Lebih baik perusahaan keluarga etnis Tionghoa yang dipilih lebih tersebar dan hanya 1 orang yang menjadi pemegang kendali diwawancarai masing-masing perusahaan demi mendapatkan data yang jauh lebih kaya dan mendalam. Pemilihan perusahaan akan lebih baik jika lebih bervariasi. Penelitian selanjutnya hendaknya berfokus padaMembandingkan sistem pengendalian manajemen budaya perusahaan keluarga lokal dan keturunan Tionghoa agar dapat mengidentifikasi agenda-agenda yang mungkin dapat dikembangkan sebagai sebuah tradisi inovatif dan produktif bagi perkembangan pengetahuan,praktik,dan akuntabilitas di Indonesia.

2. Perusahaan keluarga etnis Tionghoa UD.KBF

a. Pimpinan perusahaanUD.KBF hendaknya melaksanakan pelatihan tentang peningkatan kinerja, sehingga skill dan jobdesk yang ada sesuai dengan apa yang diharapkan.

b. Pimpinan hendaknya setiap bagian didalam perusahaan harus ada kepala divisi yang mengontrol dan mengarahkan jalannya kegiatan usaha agar setiap permasalahan bisa diatasi dan diberi evaluasi terlebih dahulu kepala bagian yang ada.

\section{DAFTAR PUSTAKA}

Anthony, Robert N. dan V. Govindarajan. (2012). Management Control Systems. Homewood, IL: Irwin/McGraw-Hill.

Arikunto, Suharsimi. (2010). Prosedur Penelitian Suatu Pendekatan Praktik. Jakarta: RinekaCipta.

Efferin, S., dan B. Soeherman. (2010). Seni Perang Sun Zi dan Sistem Pengendalian Manajemen. PT Elex Media Komputindo: Jakarta.

Efferin, Sujoko S. (2014). Metode Penelitian Untuk Akuntansi. Malang: Bayumedia Publishing.

Efferin, S. (2015). Akuntansi, Spiritualitas, dan Kearifan Lokal: Beberapa Agenda Penelitian Kritis. Jurnal Akuntansi Multiparadigma, 6(3), 466-480.

Efferin, S., \& Hopper, T. (2007). Management control, culture and ethnicity in a Chinese Indonesian company. Accounting, Organizations and Society, 32(3), 223-262.

Erniwati. (2011). Cina Padang dalam Dinamika Ma-syarakat Minangkabau: Dari Revolusi sampai Reformasi. Disertasi S3. Jakarta: Program Stu-di Ilmu Sejarah, Fakultas Ilmu Budaya, Uni-versitas Indonesia.

Henri, J. F.(2006).“Management control systems and strategy", Accounting, Organizations and Society, 31 (6): pp. 529-558.

Sugiyono. (2015). Metode Penelitian Kuantitatif Kualitatif R\&B. Bandung: Aflabeta

Sugiyono. (2013). Metode Penelitian Pendekatan Kuantitatif, Kualitatif, dan R\&D. Bandung: Alfabeta.

Suryadinata, L.(2002).Negara dan Etnis Tionghoa: Kasus Indonesia.LP3S: Jakarta

Susanto, A.B. (2015). Membangun Perusahaan Keluarga Berkelas Dunia. Jakarta: Quantum Bisnis dan Manajemen

Tucker, B., Thorne, H., and Gurd, B. (2009). "Management control and strategy - What's been happening", Journal of Accounting Literature, 28 (2): pp. 123-163.

Villalonga, B., \& Amit, R. (2006). How Do Family Ownership, Management, and Control Affect Firm Value? Journal of Financial Economics, 80, 385-413. 